\title{
高温高圧下におけるエタノール予混合火炎の燃焼メカニズムに関する研究 A Study on Reaction Mechanism of Ethanol Premixed Flame at Elevated Pressure and Elevated Temperature
}

\author{
○正 大上 泰寛（東北大） \\ 小関 雅人（東北大） \\ 鈴木 拓朗（東北大） \\ 正 小林 秀昭（東北大） \\ 正 奥山 昌紀（東北大）
}

Yasuhiro Ogami, Masato Ozeki, Masaki Okuyama, Takuro Suzuki and Hideaki Kobayashi Institute of Fluid Science, Tohoku University, 2-1-1 Katahira, Aoba-ku, Sendai, Miyagi 980-8577

\begin{abstract}
Laminar burning velocities for ethanol/air premixed flames were measured in elevated pressure and elevated temperature conditions by using the local angle method which employs particle tracking velocimetry (PTV) to Bunsen flames. Experimental data of laminar burning velocities were compared with numerical results calculated using detailed chemical reaction mechanisms for ethanol oxidation, i.e., the mechanism by Marinov and the mechanism by Saxena and Williams, and the validation of the existing chemical reaction mechanisms was performed under high pressure and high temperature conditions.
\end{abstract}

Key Words: Laminar burning velocity, High pressure, High temperature, Ethanol, Chemical reaction Mechanism

\section{1.はじめに}

エタノールはバイオ燃料の一つでる。 また，基本的なア ルコール燃料の一つであることから，高級アルコール系燃 料の燃焼反応メカニズムの解明において，エタノール燃焼 反応機構の解明は重要である。しかしながら，実験デー夕 が限られていることから，エタノール燃焼反応機構に関し ては，高温，高圧といった広い条件下において十分に議論 されているとは言えない。本研究では，圧力 $0.3 \mathrm{MPa}$, 混 合気初期温度 $500 \mathrm{~K}$ までの高温, 高圧下において $\mathrm{C}_{2} \mathrm{H}_{5} \mathrm{OH} / \mathrm{air}$ 予混合火炎の層流燃焼速度の測定を行うと共に, 詳細反応機構を用いた数值計算結果と比較することで，高 温, 高圧下に㧍ける $\mathrm{C}_{2} \mathrm{H}_{5} \mathrm{OH}$ 詳細反忘機構の検証を行った.

\section{2. 実験, 数値計算方法}

実験は, 内径 $250 \mathrm{~mm}$, 高さ $1050 \mathrm{~mm}$ の高圧燃焼容器を 用いて行った，空気およびェタノールは，二流体噴霧ノズ ルにより気液混相流となり, 水蒸気発生装置内で蒸気化さ れ, スイスロール式加熱装置で設定温度まで加熱された後, 矩形ノズルバーナーへと供給される。本研究では，压力に 応じ, 出口寸法 $12 \mathrm{~mm} \times 36 \mathrm{~mm}, 8 \mathrm{~mm} \times 30 \mathrm{~mm}, 6 \mathrm{~mm} \times 20$ $\mathrm{mm}$ の 3 種類のバーナーを用いた。層流燃焼速度の測定に は, 粒子追跡速度計法 (Particle Tracking Velocimetry, PTV) を利用した、レーザー光軸より $90^{\circ}$ の方向には，2 台の高 解像度 CMOS カメラが設置されており, それぞれ混合気中 に混入された $\mathrm{SiO}_{2}$ 粒子からのミ一散乱光と, 火炎直接画像 を同時に撮影した. 粒子画像に対しPTV 処理を行うことで 火炎断面全域における速度べクトルを計算し，また，火炎 直接画像より火炎帯の角度を導出する。これらの情報を用 い, 伸長率が低くバーナーへの熱損失が無視できる領域に おいて，火炎全域にわたり局所的に角度法を行うことで， 層流然焼速度 $S_{L}$ を導出した。なお，高圧下においては，境 界層厚さ減少に伴い局所流速と平均流速の差が数\%以内に 収まることから，S $S_{L}$ は従来の角度法により決定した。

数值計算は CHEMKIN-II ${ }^{(1)}$ ， PREMIX ${ }^{(2)}$ を用いて行った。 エタノール詳細反応機構としては，Marinov の詳細反応機 構 $^{(3)}$, Saxena and Williams の詳細反応機構 ${ }^{(4)}$ を用いた。

\section{3. 実験および数值計算結果}

3.1 常温, 大気圧下における層流燃焼速度

Fig. 1 は，室温，大気圧下における $\mathrm{C}_{2} \mathrm{H}_{5} \mathrm{OH} /$ air 火炎の $S_{L}$ と
当量比媓関係を示したものである，図中には，他の研究者 による測定結果 ${ }^{(5-10)}$ と, Marinov ${ }^{(3)}$ およよび Saxena and Williams ${ }^{(4)}$ の反応機構を用いた計算結果も示されている.. 本測定結果は, 最新の測定結果の一つで平面火炎法により得られた Konnovら ${ }^{(5)}$ の測定結果と良い一致を示していることがわかる。一方，そ

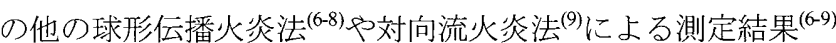
においては，量論比付近において非常に大きなばらつきが見ら れる.これらの手法は，測定結果を非伸長の状態に外挿するこ とで $S_{L}$ を決定するものであるが，室温，大気圧下における $\mathrm{C}_{2} \mathrm{H}_{5} \mathrm{OH} / \mathrm{air}$ 火炎のマークスタイン数は 6 程度と大きいことか $ら^{(6)}$ ，外挿手法の違いが測定結果に大きな影響を及ぼしている と考えられる。すなわち，マークスタイン数の大きい $\mathrm{C}_{2} \mathrm{H}_{5} \mathrm{OH} / \mathrm{air}$ 火炎においては, 火炎伸長に対して補正を行う必要 のない本測定法は， $S_{L}$ の測定に適した手法であるといえる.

Marinov ${ }^{(3)}$ および Saxena and Williams ${ }^{(4)}$ の 2 つの反応機構間で は，当量比 0.8 以上の条件下において大きな差異が見られ， Marinov の反応機構 (3)を用いた計算結果は Saxena and Williams の反応機構を尔を用いた計算結果に比べ小さな值となる、いずれ の計算結果も, 全体的に Gülder ${ }^{(8)}$ や Egolofopoulos ら ${ }^{(9)}$ のデータ に近い值を示しているが，これは，Marinov の反応機構 ${ }^{(3)}$ は Gülder $^{(8)}$ と Egolofopoulos ら ${ }^{(9)}$ の実験データを, Saxena and Williams の反応機構 ${ }^{(4)}$ は Egolofopoulos $ら^{(9)}$ の実験データを参考 にして作成されたためである。一方，最新のデータである本測 定結果やKonnov $ら^{(5)}$, Bradley ら ${ }^{(7)}$ による測定結果に対しては, 過濃条件下では Marinov の反応機構 ${ }^{(3)}$ を用いた計算結果は測定 結果に比心゙て若干下回るものの概ね良い一致を示しているが， 希薄条件下ではいずれの反応機構の計算結果も測定結果に比べ 大きな值となる.

\section{2 層流然焼速度の温度依存性}

Fig.2 は，大気圧下における $S_{L}$ と混合気初期温度 $T$ との 関係を示したものである. 2 つの詳細反応機構 ${ }^{(3,4)}$ を用いた 計算結果は，いずれの当量比においても $T=298 \mathrm{~K}$ におい ては良い一致を示しているものの，Tの増大に伴い差異が 増大していくことがわかる. また，当量比 0.8 の条件下に おいては，いずれの混合気初期温度においても，測定結果 は Marinovの反応機構 ${ }^{(3)}$ を用いた計算結果を若干下回るも のの近い值となっている. また，当量比 1.0 においては, 測定結果は Marinov の反応機構 ${ }^{(3)}$ を用いた計算結果に非常 に良い一致を示す。一方, 当量比 1.3 においては, 測定結 
果はSaxena and Williams の反応機構(4)を用いた計算結果に 近い值となった. 以上の結果から, 現有の詳細反応機構で は，広い当量比条件下においては，測定結果に見られる $S_{L}$ の温度依存性を再現することができないことがわかった。

\section{3 層流燃焼速度の温度依存性}

Fig. 3 は, $T=400 \mathrm{~K}$ における $S_{L}$ と圧力 $P$ との関係を示し たものである. 全ての当量比において, 圧力増大に伴い測 定結果と $2 つ$ 詳細反応機構を用いた計算結果閒の差異に 大きな変化が見られないことから，いずれの反応機構も測 定結果と同様の圧力依存性を有していると考えられる。し かしながら, 温度依存性の場合と同様, 測定結果と近い傾 向を示す反応機構は当量比によって異なる。すなわち, 希 薄側では測定結果はいずれの計算結果と比べ小さい值であ り, 当量比 1.0 付近では Marinovの反応機構(3)を用いた計算 結果と良い一致を示し, 過濃側では Saxena and Williams の 反応機構 ${ }^{(4)}$ を用いた計算結果に近い值となる。

\section{$3.4 \mathrm{C}_{2} \mathrm{H}_{5} \mathrm{OH} / \mathrm{air}$ 火炎における支配的素反応}

上述したように，いずれの反応機構 ${ }^{(3,4)}$ も， $S_{L}$ の温度，圧 力依存性は測定結果に近い傾向を有してはいるものの, 測 定結果と近い傾向を示す反応機構は当量比によって異なる. そこで, Saxena and Williamsの反応機構 ${ }^{(4)} に$ 対して感度解 析を行った結果, 混合気初期温度の違いによる各素反忘の 感度係数の違いは小さいが, 当量比の違いによる素反応の 感度係数の変化が大きいことがわかった.すなわち, 希薄, 量論比条件下においては, $\mathrm{CO}+\mathrm{OH}=\mathrm{CO}_{2}+\mathrm{H}$ (反応 1）は 大きな正の感度を有し, 過濃条件下では, Fall-off 反応であ る $\mathrm{CH}_{3}+\mathrm{H}(+\mathrm{M})=\mathrm{CH}_{4}(+\mathrm{M})$ (反応 2 ) が，とりわけ高圧下 に掠いて大きな負の感度を有している。特に，CO から最 終生成物である $\mathrm{CO}_{2}$ を生成する反応 1 が大きな正の感度を 有していることは, 燃料の分解に関わる素反忘が重要とな る $\mathrm{CH}_{4}$ /air 火炎の場合と大きく異なる. 反応経路解析結果 によると, $\mathrm{CO}_{2}$ の生成のほぼ全てが反応 1 によるものであ る. 一方, $\mathrm{C}_{2} \mathrm{H}_{5} \mathrm{OH}$ の分解には $\mathrm{CH}_{3} \mathrm{CHOH}, \mathrm{CH}_{3} \mathrm{CH}_{2} \mathrm{O}$, $\mathrm{CH}_{2} \mathrm{CH}_{2} \mathrm{OH}, \mathrm{C}_{2} \mathrm{H}_{4}$ 等を経由する多数の大きな経路が存在し ている.すなわち, 燃料の分解は多数の経路が存在するた 速く進行するものの, 最終的な $\mathrm{CO}_{2}$ の生成は反応 1 のみ に依存しボトルネックとなっていることから, 反応 1 が大 きな正の感度を有しているものと考えられる。

\section{4. 結言}

高温, 高压下において, $\mathrm{C}_{2} \mathrm{H}_{5} \mathrm{OH} / \mathrm{air}$ 予混合火炎の層流燃 焼速度の測定を行うと共に, 測定結果を用いたエタノール 反忘機構の検証を行った。その結果，測定結果と近い層流 燃焼速度の温度, 圧力依存性を有する反応機構は, 当量比 によって異なることがわかった。

\section{参考文献}

(1) Kee, R.J. et al., Sandia Report SAND85-8240 (1991).

(2) Kee, R.J. et al., Sandia Report SAND89-8009 (1989).

(3) Marinov, N.M. et al., Chem. Kinetics, 31 (1999), 183.

(4) Saxena, P. et al., Proc. Combust. Inst., 31 (2007), 1149.

(5) Konnov. A.A. et al., Proc. Combust. Inst., 33 (2011), 1011.

(6) Bradley, D. et al., Combust. Flame, 156 (2009), 1462.

(7) Kwon, O.C. et al., J. Propul. Power, 16 (2000), 513.

(8) Egolofopoulos, F.N. et al., 24th Symp. Combust. (1992), 833.

(9) Gülder, Ö, 19th Symp. Combust., (1982), 275.

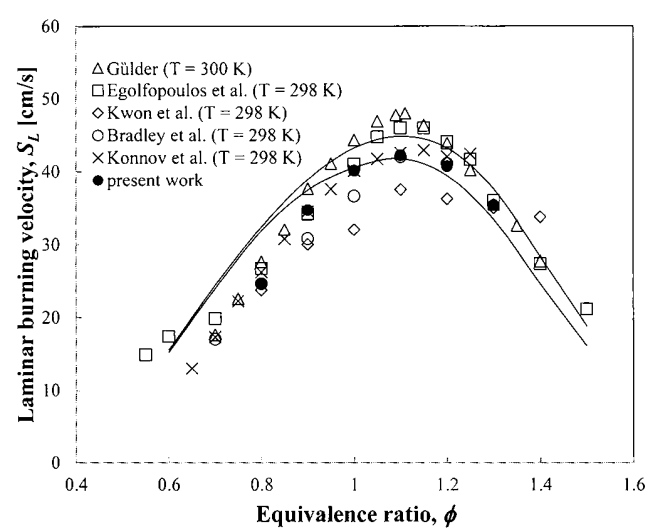

Fig. 1 Variation of $S_{L}$ to $\phi\left(\mathrm{C}_{2} \mathrm{H}_{5} \mathrm{OH} /\right.$ air, $\left.P=0.1 \mathrm{MPa}\right)$

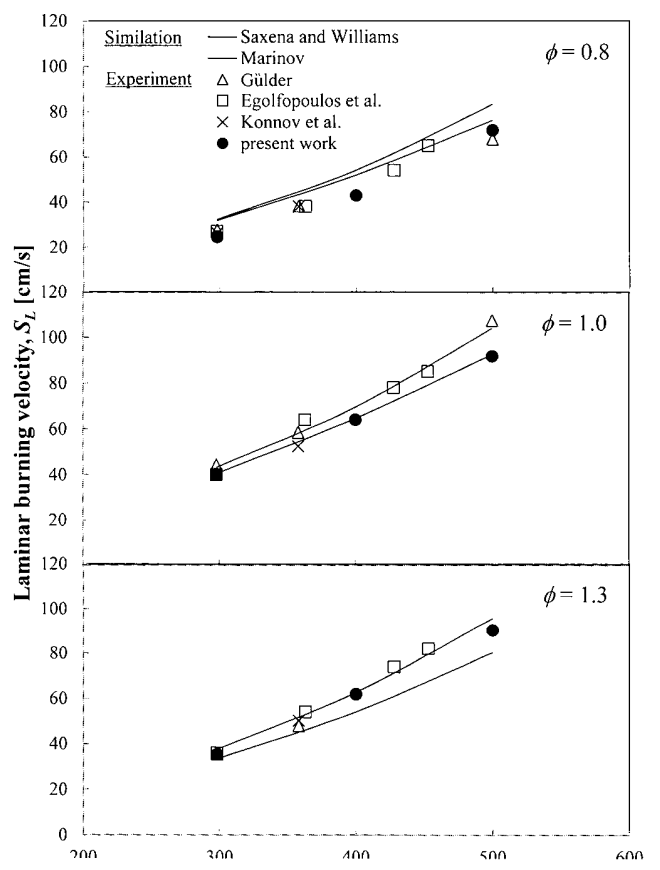

Fig. 2 Variation of $S_{L}$ to $T\left(\mathrm{C}_{2} \mathrm{H}_{5} \mathrm{OH} /\right.$ air, $\left.P=0.1 \mathrm{MPa}\right)$

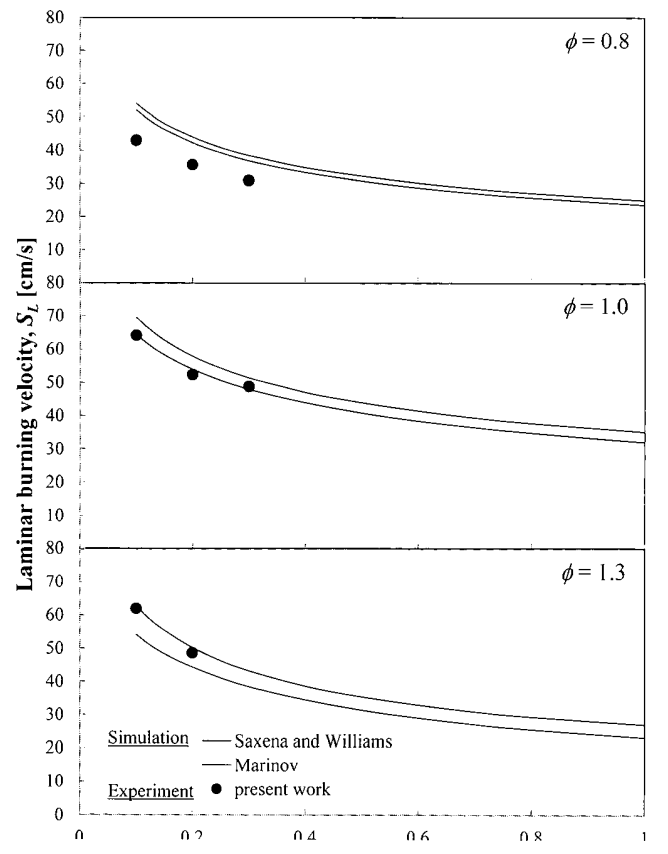

Fig. 3 Variation of $S_{L}$ to $P\left(\mathrm{C}_{2} \mathrm{H}_{5} \mathrm{OH} /\right.$ air, $\left.T=400 \mathrm{~K}\right)$ 